\title{
PRODUCTION OF SEEDLINGS OF COLUBRINA GLANDULOSA PERKINS WITH DRILLING WASTE FROM OIL WELLS AND MYCORRHIZAL INOCULATION
}

\author{
Ana Caroline Rodrigues Silva ${ }^{1}$, Rodrigo Camara ${ }^{2}$, Marcos Gervasio Pereira ${ }^{3 *}$, Júlio César Ribeiro ${ }^{4}$, \\ Joel Quintino Oliveira Filho ${ }^{5}$, Everaldo Zonta ${ }^{6}$ \\ ${ }^{1}$ Universidade Federal Rural do Rio de Janeiro - Programa de Pós-Graduação em Ciências Ambientais e Florestais, Seropédica, Rio de \\ Janeiro, Brasil - aana.r@hotmail.com \\ ${ }^{2}$ Universidade Federal Rural do Rio de Janeiro - Programa de Pós-Graduação em Ciências Ambientais e Florestais, Seropédica, Rio de \\ Janeiro, Brasil - rcamara73@gmail.com.br \\ ${ }^{3 *}$ Universidade Federal Rural do Rio de Janeiro - Departamento de Solos, Seropédica, Rio de Janeiro, Brasil - \\ mgervasiopereira01@gmail.com \\ ${ }^{4}$ Universidade Federal Rural do Rio de Janeiro - Departamento de Solos, Seropédica, Rio de Janeiro, Brasil - jcragricola@ hotmail.com \\ ${ }^{5}$ Universidade Federal Rural do Rio de Janeiro - Programa de Pós-Graduação em Ciências Ambientais e Florestais, Seropédica, Rio de \\ Janeiro, Brasil - joelquintino@yahoo.com.br \\ ${ }^{6}$ Universidade Federal Rural do Rio de Janeiro - Departamento de Solos, Seropédica, Rio de Janeiro, Brasil - ezonta@ufrrj.br
}

Received for publication: 26/03/2020 - Accepted for publications: 29/07/2020

\begin{abstract}
Resumo
Produção de mudas de Colubrina glandulosa Perkins com resíduo de perfuração de poços de petróleo e inoculação micorrízica. A exploração de petróleo, seja onshore ou offshore, resulta em resíduos da perfuração dos poços, denominados cascalho. O emprego desse passivo ambiental na produção de mudas para a restauração florestal pode contribuir para a correta destinação desse resíduo. No presente estudo, objetivou-se avaliar o efeito do substrato formulado com cascalho, com e sem inoculação com fungos micorrízicos arbusculares (FMA), sobre o crescimento e estado nutricional de mudas de Colubrina glandulosa. O delineamento utilizado foi inteiramente casualizado em esquema fatorial $5 \times 2$, com cinco doses de cascalho $(0,5,10,15$ e $20 \%)$, com e sem inoculação com uma mistura de esporos de FMA (Gigaspora margarita, Rhizophagus clarus e Dentiscutata heterogama) com seis repetições, totalizando 60 unidades experimentais. Avaliou-se altura (H) e diâmetro do coleto (DC) aos 30, 60, 90 e 120 dias após a repicagem das mudas, quando as plantas foram seccionadas em parte aérea (galhos+folhas) e raízes, para determinação da biomassa seca de parte aérea (DMS) e de raízes (DMR), índice de área foliar (IAF), taxa de comprimento de raízes finas colonizadas por FMA (COL) e composição química. O substrato obtido com a aplicação da menor dose de cascalho (5\%), sem a inoculação micorrízica, proporcionou incrementos significativos em H, DC, IAF, DMS, DMR e COL das mudas de Colubrina glandulosa, quando comparado às demais doses de cascalho e à presença de inoculação micorrízica, aos 120 dias após a repicagem das mudas.
\end{abstract}

Palavras-chave: Fungos micorrízicos arbusculares, cascalho de perfuração, restauração florestal, sobrasil, substrato.

\begin{abstract}
Oil exploration, whether onshore or offshore, results in residues from the drilling of wells, called gravel. The use of this environmental liability in the production of seedlings for forest restoration could contribute to an appropriate destination for this waste. In the present study, the objective was to evaluate the effect of the substrate formulated with gravel, with and without inoculation with arbuscular mycorrhizal fungi (AMF), on the growth and nutritional status of seedlings of Colubrina glandulosa. The design used was completely randomized in a $5 \times 2$ factorial scheme, with five gravel doses $(0,5,10,15$, and 20\%), with and without inoculation with a mixture of AMF spores (Gigaspora margarita, Rhizophagus clarus, and Dentiscutata heterogama) with six repetitions, totaling 60 experimental units. Height $(\mathrm{H})$ and stem diameter (SD) were evaluated at 30,60,90, and 120 days after seedling transplantation, when the plants were sectioned in shoots (branches + leaves) and roots, to determine dry biomass of shoots (DMS) and of roots (DMR), leaf area index (LAI), rate of length of fine roots colonized by AMF (COL), and chemical composition. The substrate obtained with the application of the lowest gravel dose $(5 \%)$, without the mycorrhizal inoculation, provided significant increments in H, SD, LAI, DMS, DMR, and COL of the seedlings of Colubrina glandulosa, when compared to the other gravel doses and the presence of mycorrhizal inoculation, 120 days after seedling transplantation. Keywords: Arbuscular mycorrhizal fungi, drilling gravel, forest restoration, sobrasil, substrate.
\end{abstract}

\section{INTRODUCTION}

Petroleum supports the majority of the global energy matrix, with emphasis on the transport sector, and consists of the raw material for the production of the most diverse products, such as plastics, shoes, fertilizers, and cosmetics (MARTINS et al., 2015). Most of the reserve of this fossil fuel is located in offshore fields, in which wells are drilled in order to reach deposits at ever greater depths (PETROBRAS, 2020). However, this activity generates a high amount of waste with the potential for environmental contamination, such as drilling gravel, 
constituted of rock fragments of fine or coarse granulometry that reach the surface, mixed with fluids from drilling (PETROBRAS, 2020). Hereafter, this material will be denominated gravel.

The chemical composition of the gravel varies according to the type of fluid used when drilling the oil wells, which can be based on water, gas, or oil (CORRÊA et al., 2017). In general, the said fluid contains barite, caustic soda, sodium chloride, calcium hydroxide, and other synthetic components (CAENN et al., 2011), which results in a material with a saline character. The final destination of this waste includes storage in landfills, a fact that can generate soil and water contamination. In this way, the government and scientific community of several countries have been concerned with the proper final destination of this type of waste (CORRÊA et al., 2017).

Studies have been conducted in order to investigate the possibility of using residues from different activities, as constituents of the substrate in order to provide nutrients for seedlings of forest or agricultural interest. These include seedlings of Eucalyptus saligna Sm. produced on substrate formulated with different doses of waste from the paper recycling industry (FARIA et al., 2014), and of Helianthus annuus L. (sunflower) with different gravel doses (SAMPAIO JÚNIOR et al., 2015). Therefore, it is believed that the gravel can be used as a constituent of the substrate, in the production of seedlings of native tree species, with a view to planting in areas aimed at forest restoration. However, studies with this focus are necessary with regard to gravel, since, depending on the dose applied in the formulation of the substrate, the seedlings may show adequate growth or may be negatively impacted, under greenhouse conditions, due to the salinity caused by the high levels of sodium in the residue (SAMPAIO JÚNIOR et al., 2015).

Among the potential forest species used in programs for the recovery of degraded areas, Colubrina glandulosa Perkins stands out, popularly known as colubrina, sobrasil, saguaraji-vermelho, or saguari, and belonging to the Rhamnaceae family. This tree species, native to the Atlantic Forest, demonstrates potential for the sectors of production of luxury furniture, energy, cellulose, and paper (MELO JÚNIOR et al., 2019), in addition to the restoration of degraded areas, due to its rapid growth and the possibility of planting in full sun, which provides the formation of an environment favorable to the survival and development of non-pioneer species (SILVA et al., 2015).

In this scenario, the use of inoculation of seedlings with AMF is included. AMF are fungi that are obligatorily associated with the roots of most terrestrial plants and that provide an increase in height, diameter, and dry biomass of seedlings of forest species produced in a greenhouse, in comparison with the absence of inoculation, as was previously verified for seedlings of Toona ciliata M. Roem (Australian cedar) (LIMA et al., 2015) and Colubrina glandulosa (CAMARA et al., 2017). Some studies have shown that the advantage for seedlings of Apuleia leiocarpa (Vogel) J.F. Macbr (garapa), a tree species native to the Atlantic Forest, was even greater through inoculation with a mixture of different species of AMF, probably due to the synergism between AMF with different strategies for obtaining nutrients, which are transferred to the seedlings, when compared with the isolated inoculation of the same AMF species and the absence of mycorrhizal inoculation (OLIVEIRA JÚNIOR et al., 2017).

In this way, the present work aimed to evaluate the effects of the base substrate (mixture of soil collected from the surface layer of Haplic Planosol and bovine manure) formulated with different proportions of oil well drilling gravel, in the absence and presence of inoculation with a mixture of arbuscular mycorrhizal fungi (AMF), on the growth and nutritional status of Colubrina glandulosa seedlings produced in a greenhouse.

\section{MATERIAL AND METHODS}

The experiment to produce Colubrina glandulosa seedlings was conducted in a greenhouse in the municipality of Seropédica, state of Rio de Janeiro. The substrate base was obtained through a mixture of soil of Planossolo Háplico, collected from a surface level, and bovine manure from a weather-beaten pen, in the proportion 4:1 (p/p). Subsequently, part of this material was transferred to a container with a volumetric capacity of $980 \mathrm{~mL}$, with different treatments being elaborated through the addition of different proportions $(0,5,10,15$, and $20 \%$ ) of oil well drilling gravel. The drilling gravel used came from well 7-MGP 98-D BA, located in the Miranga field, in the Recôncavo Basin, state of Bahia.

After the preparation of the five substrate compositions, they were moistened and autoclaved (temperature of $120{ }^{\circ} \mathrm{C}$, pressure of $1 \mathrm{~atm}, 1$ hour) individually, in a sequence of three times, with an interval of four days between each autoclaving. Subsequently, three subsamples of each substrate were collected to carry out chemical analyses of the exchangeable nutrient contents (TEIXEIRA et al., 2017). The pseudo-total levels of the chemical elements in the soil and in the residues (gravel and manure) used in the composition of the cultivation substrates were analyzed in triplicate according to method 3050B (USEPA, 1996), and the results are presented in Table 1. 
Table 1. Pseudo-total content of chemical elements in the material used in the composition of the substrates for cultivation of Colubrina glandulosa.

Tabela 2. Teor pseudototal de elementos químicos no material utilizado na composição dos substratos para cultivo de Colubrina glandulosa.

\begin{tabular}{|c|c|c|c|c|c|c|c|c|}
\hline \multirow{2}{*}{ Material } & $\mathbf{N}$ & $\mathbf{P}$ & $\mathbf{K}$ & Ca & Mg & $\mathrm{Na}$ & $\mathbf{C u}$ & $\mathbf{N i}$ \\
\hline & \multicolumn{8}{|c|}{ 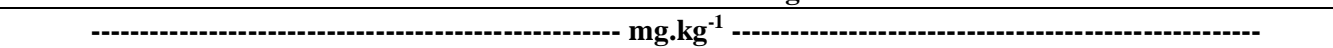 } \\
\hline Soil & $1,212.17$ & 291.04 & 190.98 & 699.67 & 98.36 & 194.43 & 2.98 & 1.95 \\
\hline Manure & $4,8229.56$ & 2075.27 & $9,851.18$ & $14,786.13$ & $6,163.21$ & $1,076.61$ & 23.26 & 4.29 \\
\hline \multirow[t]{3}{*}{ Gravel } & $3,697.10$ & 2015.90 & $1,438.20$ & $36,563.44$ & $13,267.70$ & $9,442.35$ & 43.38 & 31.22 \\
\hline & Mn & Fe & Al & $\mathrm{Cr}$ & Co & $\mathbf{Z n}$ & $\mathbf{P b}$ & \\
\hline & \multicolumn{8}{|c|}{ 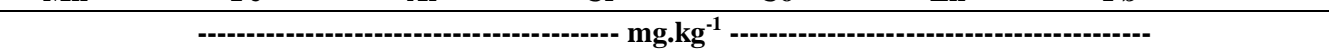 } \\
\hline Soil & 28.45 & $1,959.19$ & $9,726.84$ & 2.82 & 0,80 & 8.99 & 5.47 & \\
\hline Manure & 536.86 & $2,313.41$ & $2,906.72$ & 3.05 & 2.01 & 145.54 & 16.19 & \\
\hline Gravel & 606.42 & $29,392.07$ & $19,772.62$ & 36.12 & 15.82 & 66.41 & 18.44 & \\
\hline
\end{tabular}

The seeds of Colubrina glandulosa were immersed in a volume of concentrated sulfuric acid that corresponded to twice the volume occupied by the seeds, in a Becker glass, for 30 minutes, to break dormancy (BRANCALION et al., 2011). After this stage, the seeds were immersed in a $30 \%$ hydrogen peroxide solution, for two minutes, to eliminate possible pathogens. They were then washed with distilled water and sown with autoclaved sand for germination. After 15 days, one seedling was transferred to each plastic container with a volumetric capacity of $980 \mathrm{~mL}$, containing the substrate formulations used. Considering the soil density of $1.4 \mathrm{Mg}$ $\mathrm{m}^{-3}$, the mean value for the surface levels of Planosols in the study area, the mass value of the amount of substrate per container would be $1.4 \mathrm{~kg}$. At this moment, a standard measure $(1 \mathrm{~g})$ of mycorrhizal inoculum was added to the planting orifice in three containers within each substrate composition, in order to provide the inoculation treatment with arbuscular mycorrhizal fungi (+AMF). This inoculum consisted of soil from stock-culture of Urochloa decumbens (Stapf) R. D. Webster (brachiaria) containing spores, hyphae, and roots colonized by three AMF species: Gigaspora margarita Becker and Hall, Rhizophagus clarus Becker and Gerdemann, and Dentiscutata heterogama (Nicol and Gerd) Walker and Sanders. (OLIVEIRA JÚNIOR et al., 2017), from the Collection of Arbuscular Mycorrhizal Fungi of Embrapa Agrobiologia (COFMEA). The other three containers within each substrate composition, which did not receive the inoculum, constituted the treatments without inoculation with arbuscular mycorrhizal fungi (-AMF).

A completely randomized design in a 5x2 factorial scheme was adopted, considering five gravel doses (factor or source of variation 1), in the presence and absence of mycorrhizal inoculation (factor 2), which totaled 10 treatments, with six replications (seedlings) in each one. At 30, 60, 90, and 120 days after the seedlings were transplanted, the height $(\mathrm{H}$ in $\mathrm{cm}$ ) and stem diameter (SD in $\mathrm{mm}$ ) of the seedlings were evaluated with a centimeter ruler and digital caliper, respectively. After the last evaluation date, the seedlings were collected and fractionated in the region of the stem, for individualization between the shoots or aerial part (branches + leaves) and root system. After washing both fractions with tap water, the leaves were separated from the shoot to determine the leaf area index $\left(\mathrm{LA}\right.$ in $\left.\mathrm{cm}^{2}\right)$ using LI-COR ${ }^{\circledR}$ equipment, model LI-3100C.

Samples of fine roots $(0.5 \mathrm{~g})$ were taken from four seedlings, per treatment, and preserved in an ethanol solution $(50 \%)$ until the bleaching and staining process. The rate of length of thin roots colonized by AMF or rate of root colonization by AMF (COL\%) was determined, which was evaluated by the technique of intersection of the quadrants with adaptation to the method of root length.

Subsequently, the shoot and the root system of the seedlings were packed in individualized paper bags, for drying in an oven $\left(65^{\circ} \mathrm{C}\right.$ for $\left.72 \mathrm{~h}\right)$ with forced air circulation, in order to determine the dry biomass of the shoots (DMS in $\mathrm{g}$ ) and roots (DMR in g). After drying, the respective fractions (shoots and roots) were ground separately in a Willey mill. Due to the scarcity of plant material, it was not possible to determine the chemical composition in the dry biomass of the root system. For the dry biomass of the shoots, the evaluation of the chemical composition can only be carried out on a sample composed of the material obtained in each treatment. The $\mathrm{N}$ content in plants was determined by the Kjeldahl method, after sulfuric digestion. The contents of $\mathrm{P}, \mathrm{Na}, \mathrm{K}, \mathrm{Ca}, \mathrm{Mg}, \mathrm{Al}, \mathrm{Cu}, \mathrm{Fe}$, $\mathrm{Mn}, \mathrm{Zn}, \mathrm{Ni}, \mathrm{Cr}, \mathrm{Co}$, and $\mathrm{Pb}$ were determined after digestion by the 3050 method (USEPA, 2008). The levels of $\mathrm{P}$ in the extracts were determined using a visible light spectrophotometer. The contents of $\mathrm{Na}$ and $\mathrm{K}$ were quantified in flame spectrophotometry, and the other elements in atomic absorption spectrometry in equipment from the brand Agilent Technologies, model Varian SpectrAA 55B. 
The factor variance analysis (Factorial ANOVA) was applied to assess whether there was a significant effect of the interaction of the factors and/or a significant isolated effect isolated, on the considered variables. The data of plant growth variables (height, stem diameter, dry shoot and root biomass), in addition to the leaf area index (LAI) and root colonization rate by AMF were subjected to analysis of variance and, when the assumption of homogeneity of the variances was respected, by the Levene's test. The means of the treatments were compared by the parametric test of Tukey. When the premise was not accepted, the data were not transformed, and the treatment means were compared using the Kruskal-Wallis non-parametric test. Pearson's correlation analysis was carried out between the rates of root colonization by AMF and the chemical variables of the substrate formulations, the growth variables of the seedlings at 120 days after growing, and LAI. In these univariate statistical analyses, which were performed using the STATISTICA program, version 8.0 (StatSoft, Inc., Dell, Tulsa, USA), the significance level of 5\% was considered. It was not possible to carry out statistical analyses involving the chemical composition of dry aerial biomass, due to the reduced amount of plant material, as previously specified.

Principal component analysis was carried out in order to employ the chemical attributes of the substrates as environmental variables that explain the changes in the variables evaluated for the seedlings. For this, we considered only the variables that presented relevant correlation coefficients (>0.70) with the main axes 1 or 2 . Next, the hierarchical grouping analysis was carried out based on the Gower distance, using the simple connection method, with the aim of evaluating the similarities between the treatments. In this analysis, the inclusion criterion of variables applied in the principal components analysis was considered. Both multivariate analyses were obtained with the help of PAST software, version 2.17c (HAMMER et al., 2001).

\section{RESULTS}

The different percentages of oil well drilling gravel incorporated into the substrates provided them with a saline character (Table 2), meeting all the criteria necessary for this classification ( $\mathrm{pH}<8.5$; Electrical Conductivity (EC)> $4.0 \mathrm{dS} \mathrm{m}{ }^{-1}$; Sodium Saturation Index (SSI) <15\%) (FREIRE et al., 2013). The substrate without the application of gravel $(0 \%)$ and those with the application of the lowest doses of this residue $(5 \%$ and $10 \%$ ) presented a moderately acidic $\mathrm{pH}$ (pH: from 5.4 to 6.5 ), whereas in the applications with $15 \%$ and $20 \%$ gravel doses, the substrate was neutral (pH: 6.6-7.3) (FREIRE et al., 2013).

Table 2. Chemical analysis (exchangeable contents) of the substrates (SUB) containing different proportions of oil well drilling gravel.

Tabela 2. Análise química (teores trocáveis) dos substratos (SUB) contendo diferentes proporções de cascalho de perfuração de poços de petróleo.

\begin{tabular}{|c|c|c|c|c|c|c|c|c|c|c|c|c|c|}
\hline \multirow[t]{2}{*}{ SUB } & pH $\left(\mathrm{H}_{2} \mathrm{O}\right)$ & SEC & $\mathbf{P}$ & $\mathbf{K}^{+}$ & $\mathrm{Ca}^{2+}$ & $\mathrm{Mg}^{2+}$ & $\mathrm{Na}^{+}$ & $\mathbf{A l}^{3+}$ & $\mathbf{H}^{+}+\mathbf{A l}^{3+}$ & SB & CEC & $\mathbf{V}$ & SSI \\
\hline & & dS.m ${ }^{-1}$ & mg.kg-1 & \multicolumn{8}{|c|}{ - } & \multicolumn{2}{|c|}{----\%--- } \\
\hline $0 \%$ & 5.72 & 1.38 & 20.79 & 0.14 & 2.00 & 2.00 & 0.03 & 0,00 & 3.63 & 4.17 & 7.80 & 54 & 0.38 \\
\hline $5 \%$ & 6.49 & 8.24 & 14.67 & 0.09 & 5.10 & 2.10 & 0.77 & 0.00 & 6.11 & 8.06 & 14.16 & 57 & 5.44 \\
\hline $10 \%$ & 6.36 & 9.04 & 17.10 & 0.10 & 5.70 & 2.30 & 1.01 & 0.00 & 5.45 & 9.12 & 14.56 & 61 & 6.94 \\
\hline $15 \%$ & 6.72 & 13.32 & 17.18 & 0.11 & 7.60 & 0.70 & 1.43 & 0.00 & 5.61 & 9.83 & 15.44 & 64 & 9.26 \\
\hline $20 \%$ & 6.70 & 16.42 & 18.94 & 0.10 & 7.40 & 1.10 & 2.33 & 0.00 & 4.79 & 10.92 & 15.71 & 70 & 14.84 \\
\hline
\end{tabular}

SEC: soil electrical conductivity; H+Al: potential acidity; SB: sum of bases; CEC: cation exchange capacity; V: base saturation; SSI: sodium saturation index $\left((\mathrm{Na} / \mathrm{CEC})^{*} 100\right)$

There was a significant effect of gravel doses on the height and diameter of the Colubrina glandulosa seedlings at 30,60, and 90 days after transplantation. However, a significant effect of the interaction between the factors of gravel doses and mycorrhizal inoculation was observed on both variables only at 120 days after seedling transplantation.

Considering the set of all evaluation dates, there was wide variation in the effects of gravel doses on the results obtained for height and diameter of the seedling Colubrina glandulosa. However, in general, the mean values of both variables (height and stem diameter) were significantly higher for seedlings produced on substrate to which the lowest gravel dose was applied (5\%), whose values did not show any difference. with respect to seedlings produced on the substrate without the application of gravel $(0 \%)$, regardless of mycorrhizal inoculation (Table 3). In contrast, the seedlings produced on the substrate with the doses of $20 \%$, mainly, and $15 \%$ of gravel, 
showed lower values of height and stem diameter, throughout the evaluation period, regardless of the mycorrhizal inoculation.

Table 3. Height and stem diameter values of the Colubrina glandulosa seedlings at 30, 60, 90, and 120 days after transplantation of the seedlings, on substrate with different proportions of oil well drilling gravel (SUB), in the absence and presence of inoculation with arbuscular mycorrhizal fungi (-AMF and $+\mathrm{AMF}$, respectively), in a greenhouse *.

Tabela 3. Valores de altura e diâmetro do coleto de mudas de Colubrina glandulosa aos 30, 60, 90 e 120 dias após a repicagem das mudas, em substrato com diferentes proporções de cascalho de perfuração de poço de petróleo (SUB), na ausência e presença da inoculação com fungos micorrízicos arbusculares (-AMF e $+\mathrm{AMF}$, respectivamente), em casa de vegetação*.

\begin{tabular}{|c|c|c|c|c|c|c|c|c|}
\hline \multirow[t]{3}{*}{ SUB } & -AMF & $+\mathrm{AMF}$ & -AMF & +AMF & -AMF & +AMF & -AMF & +AMF \\
\hline & \multicolumn{2}{|c|}{-----30 days----- } & \multicolumn{2}{|c|}{-----60 days----- } & \multicolumn{2}{|c|}{-----90 days----- } & \multicolumn{2}{|c|}{-----120 days----- } \\
\hline & \multicolumn{8}{|c|}{ Height (cm) } \\
\hline $0 \%$ & $\begin{array}{c}2.78 \mathrm{Aa} \\
(0.99)\end{array}$ & $\begin{array}{c}3.68 \mathrm{Aa} \\
(0.96)\end{array}$ & $\begin{array}{c}5.13 \mathrm{Aa} \\
(1.83)\end{array}$ & $\begin{array}{c}6.05 \mathrm{Aa} \\
(2.06)\end{array}$ & $\begin{array}{c}7.70 \mathrm{ABa} \\
(1.15)\end{array}$ & $\begin{array}{c}8.88 \mathrm{Aa} \\
(0.58)\end{array}$ & $\begin{array}{c}6.95 \mathrm{Ab} \\
(1.41)\end{array}$ & $\begin{array}{c}9.25 \mathrm{Aa} \\
(0.50)\end{array}$ \\
\hline $5 \%$ & $\begin{array}{c}2.70 \mathrm{Aa} \\
(0.55)\end{array}$ & $\begin{array}{c}2.58 \mathrm{Aa} \\
(0.38)\end{array}$ & $\begin{array}{c}6.35 \mathrm{Aa} \\
(2.33)\end{array}$ & $\begin{array}{c}\text { 4.17 } \mathrm{ABa} \\
(0.93)\end{array}$ & $\begin{array}{c}7.28 \mathrm{Aa} \\
(0.89)\end{array}$ & $\begin{array}{c}6.03 \mathrm{ABa} \\
(1.31)\end{array}$ & $\begin{array}{c}8.63 \mathrm{Aa} \\
(0.75)\end{array}$ & $\begin{array}{c}7.40 \mathrm{ABa} \\
(1.47)\end{array}$ \\
\hline $10 \%$ & $\begin{array}{c}2.07 \mathrm{Aa} \\
(0.15)\end{array}$ & $\begin{array}{c}2.48 \mathrm{Aa} \\
(0.88)\end{array}$ & $\begin{array}{c}2.82 \mathrm{ABa} \\
(0.77)\end{array}$ & $\begin{array}{c}3.52 \mathrm{ABa} \\
(1.29)\end{array}$ & $\begin{array}{c}4.50 \mathrm{ABCa} \\
(1.35)\end{array}$ & $\begin{array}{c}5.80 \mathrm{ABa} \\
(1.08)\end{array}$ & $\begin{array}{c}4.75 \mathrm{Bb} \\
(1.32)\end{array}$ & $\begin{array}{c}6.65 \mathrm{Ba} \\
(1.62)\end{array}$ \\
\hline $15 \%$ & $\begin{array}{c}2.26 \mathrm{Aa} \\
(0.34)\end{array}$ & $\begin{array}{c}2.15 \mathrm{Aa} \\
(0.26)\end{array}$ & $\begin{array}{c}2.76 \mathrm{ABa} \\
(0.78)\end{array}$ & $\begin{array}{c}2.65 \mathrm{ABa} \\
(0.33)\end{array}$ & $\begin{array}{c}3.80 \mathrm{BCa} \\
(1.15)\end{array}$ & $\begin{array}{c}3.58 \mathrm{Ba} \\
(0.55)\end{array}$ & $\begin{array}{c}4.38 \mathrm{Ba} \\
(1.38)\end{array}$ & $\begin{array}{c}4.00 \mathrm{Ca} \\
(0.63)\end{array}$ \\
\hline \multirow[t]{2}{*}{$20 \%$} & $\begin{array}{c}1.60 \mathrm{Aa} \\
(0.65)\end{array}$ & $\begin{array}{c}1.68 \mathrm{Ba} \\
(0.44)\end{array}$ & $\begin{array}{c}1.80 \mathrm{Ba} \\
(0.82)\end{array}$ & $\begin{array}{c}2.38 \mathrm{Ba} \\
(0.16)\end{array}$ & $\begin{array}{c}3.15 \mathrm{Ca} \\
(1.08)\end{array}$ & $\begin{array}{c}3.03 \mathrm{Ba} \\
(0.41)\end{array}$ & $\begin{array}{c}3.28 \mathrm{Ba} \\
(1.08)\end{array}$ & $\begin{array}{c}3.65 \mathrm{Ca} \\
(0.65)\end{array}$ \\
\hline & \multicolumn{8}{|c|}{ Stem diameter (mm) } \\
\hline $0 \%$ & $\begin{array}{c}1.31 \mathrm{Aa} \\
(0.40)\end{array}$ & $\begin{array}{c}1.34 \mathrm{Aa} \\
(0.30)\end{array}$ & $\begin{array}{c}1.95 \mathrm{Aa} \\
(0.98)\end{array}$ & $\begin{array}{c}2.35 \mathrm{Aa} \\
(0.63)\end{array}$ & $\begin{array}{c}3.96 \mathrm{Aa} \\
(0.23)\end{array}$ & $\begin{array}{c}3.18 \mathrm{Ab} \\
(0.18)\end{array}$ & $\begin{array}{c}3.53 \mathrm{Aa} \\
(0.59)\end{array}$ & $\begin{array}{c}3.57 \mathrm{Aa} \\
(0.16)\end{array}$ \\
\hline $5 \%$ & $\begin{array}{c}1.14 \mathrm{Aa} \\
(0.22)\end{array}$ & $\begin{array}{c}1.17 \mathrm{ABa} \\
(0.19)\end{array}$ & $\begin{array}{c}2.17 \mathrm{Aa} \\
(0.83)\end{array}$ & $\begin{array}{c}1.77 \mathrm{ABa} \\
(0.40)\end{array}$ & $\begin{array}{c}2.81 \mathrm{Aa} \\
(0.22)\end{array}$ & $\begin{array}{c}2.65 \mathrm{ABa} \\
(0.37)\end{array}$ & $\begin{array}{c}2.66 \mathrm{Ba} \\
(0.91)\end{array}$ & $\begin{array}{c}2.94 \mathrm{Aa} \\
(0.46)\end{array}$ \\
\hline $10 \%$ & $\begin{array}{c}1.17 \mathrm{Aa} \\
(0.44)\end{array}$ & $\begin{array}{c}0.85 \mathrm{Ba} \\
(0.19)\end{array}$ & $\begin{array}{c}1.37 \mathrm{ABa} \\
(0.26)\end{array}$ & $\begin{array}{c}1.57 \mathrm{BCa} \\
(0.48)\end{array}$ & $\begin{array}{c}1.72 \mathrm{ABa} \\
(0.63)\end{array}$ & $\begin{array}{c}2.40 \mathrm{ABa} \\
(0.84)\end{array}$ & $\begin{array}{c}1.81 \mathrm{Cb} \\
(0.67)\end{array}$ & $\begin{array}{c}2.65 \mathrm{Aa} \\
(0.87)\end{array}$ \\
\hline $15 \%$ & $\begin{array}{c}0.84 \mathrm{Aa} \\
(0.16)\end{array}$ & $\begin{array}{c}0.88 \mathrm{Ba} \\
(0.10)\end{array}$ & $\begin{array}{c}1.04 \mathrm{ABa} \\
(0.25)\end{array}$ & $\begin{array}{c}1.31 \mathrm{BCa} \\
(0.40)\end{array}$ & $\begin{array}{c}1.44 \mathrm{ABa} \\
(0.45)\end{array}$ & $\begin{array}{c}1.33 \mathrm{BCa} \\
(0.37)\end{array}$ & $\begin{array}{c}1.63 \mathrm{Ca} \\
(0.67)\end{array}$ & $\begin{array}{c}1.40 \mathrm{Ba} \\
(0.16)\end{array}$ \\
\hline $20 \%$ & $\begin{array}{c}0.79 \mathrm{Aa} \\
(0.10) \\
\end{array}$ & $\begin{array}{c}0.99 \mathrm{ABa} \\
(0.46)\end{array}$ & $\begin{array}{c}0.90 \mathrm{Ba} \\
(0.20) \\
\end{array}$ & $\begin{array}{c}1.03 \mathrm{Ca} \\
(0.07) \\
\end{array}$ & $\begin{array}{c}1.09 \mathrm{Ba} \\
(0.24)\end{array}$ & $\begin{array}{c}1.40 \mathrm{BCa} \\
(0.29)\end{array}$ & $\begin{array}{c}1.25 \mathrm{Cb} \\
(0.28) \\
\end{array}$ & $\begin{array}{c}1.56 \mathrm{Ba} \\
(0.34) \\
\end{array}$ \\
\hline
\end{tabular}

* Means (six repetitions) followed by the same capital letter in the column, within the same mycorrhizal inoculation treatment (-AMF or + AMF), or lowercase in the line, within the same dose of oil well drilling gravel $(0 \%, 5 \%, 10 \%, 15 \%$, or $20 \%)$, respectively, within the same evaluation date, do not differ significantly from each other $(\mathrm{p}<0.05)$. Values in parentheses refer to the standard deviation.

Significant differences were observed between the absence and presence of mycorrhizal inoculation for the height only at 120 days after transplantation, for the seedlings produced in the substrate where the $10 \%$ gravel dose was applied. Regarding the stem diameter, a significant effect of the mycorrhizal inoculation was found only at 90 days, for seedlings produced in substrate without the application of gravel, and at 120 days after transplantation, for seedlings produced in substrates with the application of $10 \%$ and $20 \%$ gravel doses. In these cases, in general, the presence of mycorrhizal inoculation promoted increments in the height and stem diameter of the seedlings, in relation to the absence of mycorrhizal inoculation.

The pattern verified for height and stem diameter was also observed for dry biomass of the shoots, dry biomass of roots, and leaf area index of seedlings of Colubrina glandulosa. In this way, the substrate with the application of the lowest gravel dose $(5 \%)$ promoted increases in the variables previously mentioned (dry biomass of shoots, dry biomass of roots, and leaf area index), when compared with the substrate with the other gravel doses, regardless of inoculation with arbuscular mycorrhizal fungi (Table 4). The effect of the substrate with the application of the $5 \%$ gravel dose did not differ from the seedlings produced on the substrate without the application of gravel $(0 \%)$,

Table 4. Values of dry biomass of the shoots (DMS) and roots (DMR), leaf area index (LAI), and rate of root colonization by MFA (COL) of seedlings of Colubrina glandulosa at 120 days after seedling transplantation, on substrate with different proportions of oil well drilling gravel (SUB), in the absence and presence of inoculation with arbuscular mycorrhizal fungi (-AMF and +AMF, respectively), in a greenhouse*. 
Tabela 4. Valores de biomassa seca de parte aérea (DMS) e de raízes (DMR), índice de área foliar (LAI) e taxa de colonização radicular por FMA (COL) de mudas de Colubrina glandulosa aos 120 dias após a repicagem das mudas, em substrato com diferentes proporções de cascalho de perfuração de poço de petróleo (SUB), na ausência e presença da inoculação com fungos micorrízicos arbusculares (-AMF e +AMF, respectivamente), em casa de vegetação*.

\begin{tabular}{|c|c|c|c|c|c|c|c|c|}
\hline \multirow[t]{3}{*}{ SUB } & -AMF & +AMF & -AMF & +AMF & -AMF & +AMF & -AMF & +AMF \\
\hline & \multicolumn{2}{|c|}{ DMS } & \multicolumn{2}{|c|}{ DMR } & \multicolumn{2}{|c|}{ LAI } & \multicolumn{2}{|c|}{ COL } \\
\hline & \multicolumn{2}{|c|}{---------------------- } & \multicolumn{2}{|c|}{ 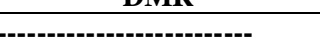 } & \multicolumn{2}{|c|}{---------cm² } & \multicolumn{2}{|c|}{------\% \%------ } \\
\hline $0 \%$ & $\begin{array}{c}1.44 \mathrm{ABa} \\
(0.65)\end{array}$ & $\begin{array}{c}1.67 \mathrm{Aa} \\
(0.25)\end{array}$ & $\begin{array}{c}0.90 \mathrm{Aa} \\
(0.60)\end{array}$ & $\begin{array}{c}1.06 \mathrm{Aa} \\
(0.14)\end{array}$ & $\begin{array}{c}115.35 \mathrm{Aa} \\
(54.33)\end{array}$ & $\begin{array}{c}131.10 \mathrm{Aa} \\
(23.88)\end{array}$ & - & $\begin{array}{c}14 \mathrm{~A} \\
(2)\end{array}$ \\
\hline $5 \%$ & $\begin{array}{c}1.56 \mathrm{Aa} \\
(0.26)\end{array}$ & $\begin{array}{c}1.17 \mathrm{ABa} \\
(0.64)\end{array}$ & $\begin{array}{c}0.90 \mathrm{Aa} \\
(0.09)\end{array}$ & $\begin{array}{c}0.76 \mathrm{ABa} \\
(0.35)\end{array}$ & $\begin{array}{c}131.92 \mathrm{Aa} \\
(27.20)\end{array}$ & $\begin{array}{c}100.02 \mathrm{ABa} \\
(62.48)\end{array}$ & - & $\begin{array}{l}10 \mathrm{~B} \\
(3)\end{array}$ \\
\hline $10 \%$ & $\begin{array}{c}0.66 \mathrm{ABa} \\
(0.52)\end{array}$ & $\begin{array}{c}1.05 \mathrm{ABa} \\
(0.81)\end{array}$ & $\begin{array}{c}0.32 \mathrm{ABa} \\
(0.43)\end{array}$ & $\begin{array}{c}0.57 \mathrm{ABa} \\
(0.50)\end{array}$ & $\begin{array}{c}45.15 \mathrm{Ba} \\
(54.36)\end{array}$ & $\begin{array}{c}105.42 \mathrm{ABa} \\
(65.85)\end{array}$ & - & $\begin{array}{l}5 \mathrm{C} \\
\text { (1) }\end{array}$ \\
\hline $15 \%$ & $\begin{array}{c}0.35 \mathrm{ABa} \\
(0.34)\end{array}$ & $\begin{array}{c}0.14 \mathrm{ABa} \\
(0.08)\end{array}$ & $\begin{array}{c}0.18 \mathrm{ABa} \\
(0.17)\end{array}$ & $\begin{array}{c}0.10 \mathrm{Ba} \\
(0.05)\end{array}$ & $\begin{array}{c}30.94 \mathrm{Ba} \\
(31.68)\end{array}$ & $\begin{array}{c}5.68 \mathrm{Ba} \\
(5.52)\end{array}$ & - & $\begin{array}{l}4 \mathrm{C} \\
(2)\end{array}$ \\
\hline $20 \%$ & $\begin{array}{c}0.11 \mathrm{Ba} \\
(0.10)\end{array}$ & $\begin{array}{c}0.21 \mathrm{Ba} \\
(0.13)\end{array}$ & $\begin{array}{c}0.06 \mathrm{Ba} \\
(0.06)\end{array}$ & $\begin{array}{c}0.13 \mathrm{Ba} \\
(0.08)\end{array}$ & $\begin{array}{c}7.45 \mathrm{Ba} \\
(8.22)\end{array}$ & $\begin{array}{c}17.63 \mathrm{ABa} \\
(11.02)\end{array}$ & - & $\begin{array}{l}2 \mathrm{C} \\
\text { (2) }\end{array}$ \\
\hline
\end{tabular}

* Means (six repetitions) followed by the same capital letter in the column, within the same mycorrhizal inoculation treatment (-AMF or $+\mathrm{AMF})$, or lowercase in the line, within the same dose of oil well drilling gravel $(0 \%, 5 \%, 10 \%, 15 \%$, or $20 \%)$, respectively, within the same evaluation date, do not differ significantly from each other $(\mathrm{p}<0.05)$. Values in parentheses refer to the standard deviation.

Regarding the rate of root colonization by MFA, the mean values were significantly higher in the absence of gravel (0\%), compared to all applied gravel doses (Table 4). In the comparison between the four gravel doses tested, the seedlings produced under the lowest dose $(5 \%)$ showed a lower rate of root colonization by MFA. High values $(>0.90)$ of significant and negative correlation were observed between the rate of root colonization by MFA and the sodium saturation index $(r=-0.9342)$, exchangeable calcium content $(r=-0.9456)$, and electrical conductivity $(r=-0.9463)$ in the substrate. High values of significant correlation were also verified between the rate of root colonization by MFA and height, stem diameter, dry shoot and root biomass, however these values were positive $(r=0.9383 ; 0.9104 ; 9028$; and 9418, respectively). There were no significant correlations between the leaf area index, the other edaphic variables, including $\mathrm{pH}$ and phosphorus availability, and the rate of root colonization by MFA.

In general, there was a tendency for higher absolute values of levels of chemical elements in the shoots, for seedlings produced in substrate with the two highest gravel doses applied (15\% and 20\%), regardless of inoculation with mycorrhizal fungi (Table 5).

Table 5. Content of chemical elements in the dry biomass of the shoots of seedlings of Colubrina glandulosa at 120 days after seedling transplantation, on substrate with different proportions of oil well drilling gravel (SUB), in the absence and presence of inoculation with arbuscular mycorrhizal fungi (-AMF and +AMF, respectively), in a greenhouse.

Tabela 5. Teor de elementos químicos na biomassa seca da parte aérea de mudas de Colubrina glandulosa aos 120 dias após a repicagem das mudas, em substrato com diferentes proporções de cascalho de perfuração de poço de petróleo (SUB), na ausência e presença da inoculação com fungos micorrízicos arbusculares (AMF e +AMF, respectivamente), em casa de vegetação.

\begin{tabular}{|c|c|c|c|c|c|c|c|c|c|c|}
\hline \multirow[t]{3}{*}{ SUB } & $-\mathbf{A M F}$ & $+\mathbf{A M F}$ & -AMF & $+\mathrm{AMF}$ & $-\mathbf{A M F}$ & $+\mathrm{AMF}$ & -AMF & $+\mathrm{AMF}$ & -AMF & $+\mathrm{AMF}$ \\
\hline & \multicolumn{2}{|c|}{$\mathbf{N}$} & \multicolumn{2}{|c|}{$\mathbf{P}$} & \multicolumn{2}{|c|}{$\mathbf{K}$} & \multicolumn{2}{|c|}{$\mathbf{C a}$} & \multicolumn{2}{|c|}{ Mg } \\
\hline & \multicolumn{10}{|c|}{ 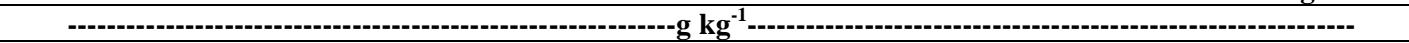 } \\
\hline $0 \%$ & 13.40 & 14.47 & 6.38 & 5.60 & 22.84 & 19.48 & 11.12 & 11.39 & 2.78 & 2.57 \\
\hline $5 \%$ & 20.10 & 24.12 & 5.28 & 6.41 & 29.26 & 28.82 & 14.27 & 10.08 & 1.47 & 1.38 \\
\hline $10 \%$ & 27.09 & 24.98 & 6.61 & 5.24 & 39.24 & 31.34 & 18.93 & 18.88 & 2.12 & 1.55 \\
\hline $15 \%$ & 23.66 & 61.96 & 6.33 & 6.63 & 28.44 & 60.55 & 17.85 & 26.81 & 1.99 & 4.46 \\
\hline \multirow[t]{3}{*}{$20 \%$} & 93.32 & 32.95 & 5.58 & 5.35 & 107.38 & 41.00 & 61.76 & 12.76 & 7.72 & 2.66 \\
\hline & \multicolumn{2}{|c|}{$\mathrm{Na}$} & \multicolumn{2}{|c|}{ Al } & \multicolumn{2}{|c|}{$\mathrm{Cu}$} & \multicolumn{2}{|c|}{ Fe } & \multicolumn{2}{|c|}{ Mn } \\
\hline & \multicolumn{4}{|c|}{ 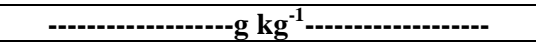 } & \multicolumn{6}{|c|}{ 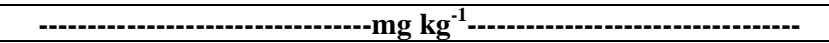 } \\
\hline $0 \%$ & 0.26 & 0.14 & 0.10 & 0.06 & 1.53 & 2.06 & 105.27 & 105.91 & 54.26 & 42.07 \\
\hline $5 \%$ & 0.31 & 0.20 & 0.08 & 0.06 & 2.47 & 1.87 & 94.38 & 90.59 & 24.77 & 25.89 \\
\hline $10 \%$ & 0.49 & 0.30 & 0.04 & 0.04 & 1.83 & 0.66 & 82.30 & 81.99 & 41.61 & 25.59 \\
\hline $15 \%$ & 0.66 & 0.92 & 0.05 & 0.14 & 3.46 & 4.83 & 99.42 & 174.43 & 43.51 & 107.73 \\
\hline $20 \%$ & 4.86 & 1.74 & 0.14 & 0.06 & 3.12 & 3.58 & 194.19 & 76.47 & 188.17 & 58.41 \\
\hline
\end{tabular}




\begin{tabular}{|c|c|c|c|c|c|c|c|c|c|c|}
\hline & \multicolumn{2}{|c|}{ Zn } & \multicolumn{2}{|c|}{$\mathbf{N i}$} & \multicolumn{2}{|c|}{ Co } & \multicolumn{2}{|c|}{$\mathrm{Cr}$} & \multicolumn{2}{|c|}{$\mathbf{P b}$} \\
\hline & \multicolumn{10}{|c|}{ 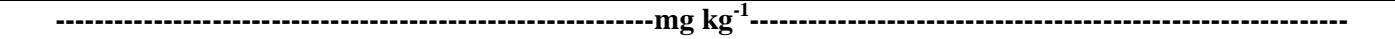 } \\
\hline $0 \%$ & 24.30 & 17.76 & 2.14 & 1.82 & 0.48 & 0.45 & 2.05 & 3.34 & 28.78 & 22.39 \\
\hline $5 \%$ & 17.69 & 14.71 & 1.31 & 1.41 & 0.26 & 0.82 & 3.52 & 1.98 & 40.06 & 24.45 \\
\hline $10 \%$ & 19.96 & 12.42 & 0.67 & 0.03 & 0.92 & 0.41 & 0.49 & 1.26 & 22.01 & 19.77 \\
\hline $15 \%$ & 15.94 & 31.76 & 3.88 & 1.43 & 0.58 & 2.95 & 4.55 & 2.50 & 24.99 & 61.69 \\
\hline $20 \%$ & 82.46 & 26.43 & 7.69 & 0.71 & 0.62 & 1.06 & 8.94 & 0.61 & 155.94 & 28.06 \\
\hline
\end{tabular}

The relationship between principal components 1 and 2 of the multivariate principal components analysis demonstrated the separation of the treatments from each other (Figure 1A). Regarding principal component 1, which explained most of the data variability (eigenvalue of approximately 74\%), the treatments with the absence of gravel (0\%) and with the lowest doses of gravel (5\% and 10\%), were located in the region to the left (negative eigenvectors) of that Figure, regardless of inoculation with mycorrhizal fungi. On the other hand, treatments with the highest gravel doses (15\% and 20\%, respectively), were shown to the right (positive eigenvectors) of this same component, regardless of the inoculation of Colubrina glandulosa seedlings with arbuscular mycorrhizal fungi.

Considering axis 2, which explained approximately $18 \%$ of the data variability, it was observed that the treatments $0 \%$-AMF, $0 \%+\mathrm{AMF}$, and $20 \%$-AMF were located in the upper portion (positive eigenvectors) of Figure 1A, while the other treatments (5\%-AMF, 5\%+AMF, 10\%-AMF, 10\%+AMF, 15\%-AMF, 15\%+AMF, and $20 \%+\mathrm{AMF}$ ) were distributed in the lower portion (negative eigenvectors) of that axis. The multivariate principal components analysis explained approximately $92 \%$ of the total variability of the observed data.

Through the analysis of Figure 1A, it was also observed that the $0 \%-\mathrm{AMF}$ and $0 \%+\mathrm{AMF}$ treatments correlated with higher values of all the growth variables of the seedling Colubrina glandulosa (H: height; SD: stem diameter; DMS and DMR: dry biomass of shoots and roots, respectively; LAI: leaf area index) and $\mathrm{Mg}$ availability in the substrate. On the other hand, the 15\%-AMF, 15\%+AMF, and 20\%+AMF correlated with higher $\mathrm{pH}$ values, soil electrical conductivity (SEC), sum of bases (SB), cation exchange capacity (CEC), base saturation (BS), sodium saturation index (SSI), and availability of $\mathrm{Ca}$ and $\mathrm{O}$ in the substrate.

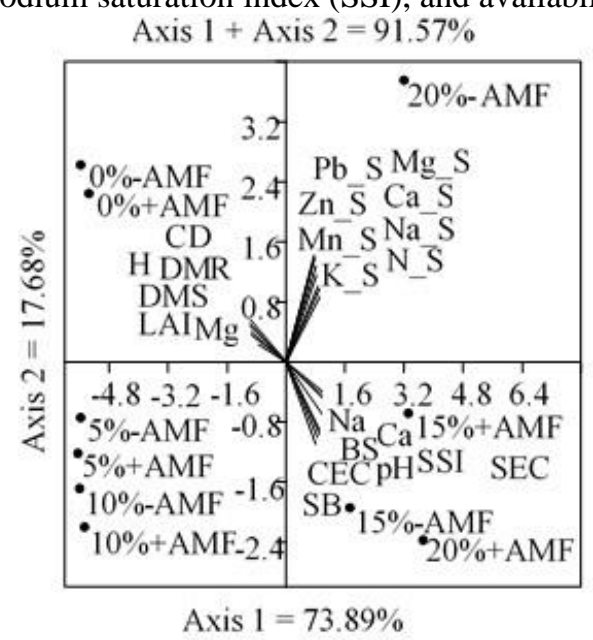

(A)

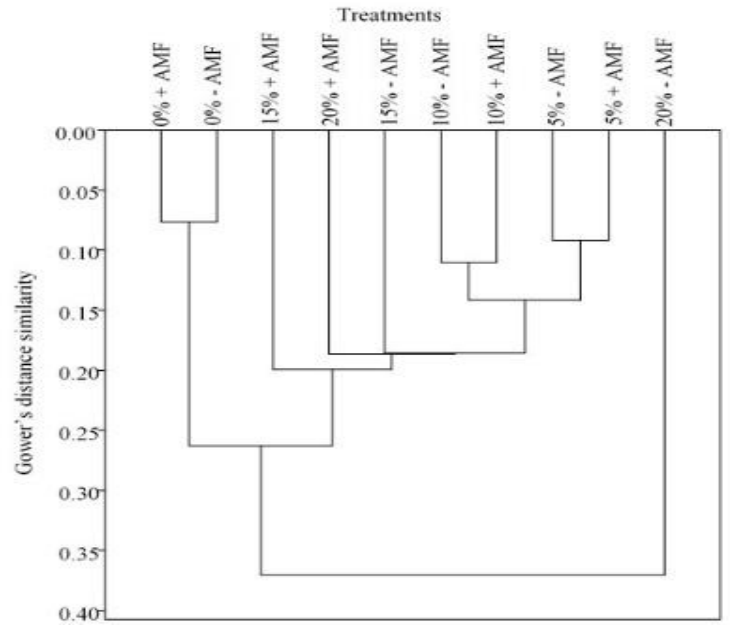

(B)

Figure 1. Principal component analysis (A) and hierarchical clustering dendrogram for the chemical variables of the substrate, growth, and contents of chemical elements in the dry shoot biomass of seedlings of Colubrina glandulosa at 120 days after seedling transplantation, on substrate with different proportions of oil well drilling gravel, with and without inoculation with arbuscular mycorrhizal fungi (+AMF and -AMF, respectively), in a greenhouse.

Figura 1. Análise de componentes principais e dendrograma de agrupamento hierárquico para as variáveis químicas do substrato, de crescimento e teores de elementos químicos na biomassa seca de parte aérea de mudas de Colubrina glandulosa aos 120 dias após a repicagem das mudas, em substrato com diferentes proporções de cascalho de perfuração de poços de petróleo, sem e com a inoculação com fungos micorrízicos arbusculares (-AMF e +AMF, respectivamente), em casa de vegetação.

The 20\% -AMF treatment correlated with higher absolute values of $\mathrm{N}, \mathrm{K}, \mathrm{Ca}, \mathrm{Mg}, \mathrm{Mn}, \mathrm{Zn}, \mathrm{Na}$, and $\mathrm{Pb}$ in the shoots of the seedlings of Colubrina glandulosa (Figure 1A). The treatments 5\%-AMF, 5\%+AMF, 10\%-AMF, and $10 \%+\mathrm{AMF}$ did not present a correlation with any of the variables analyzed. 
The analysis of the hierarchical clustering dendrogram reinforced the pattern of individualization of the tested treatments, which was previously pointed out by the principal components analysis. Figure 1B indicates the individualization of treatments in two major distinct groups. One of these was represented only by the treatment in which the highest dose of gravel was applied in the absence of inoculation with arbuscular mycorrhizal fungi (20\%-AMF).

The other large group brought together all the other treatments tested and was subdivided into two subgroups. One subgroup was constituted by the treatments in which the gravel was not applied, in the absence and presence of inoculation of seedlings of Colubrina glandulosa with arbuscular mycorrhizal fungi (0\%-AMF and $0 \%+\mathrm{AMF}$, respectively). The second subgroup was formed by the combination of treatments in which the doses of $5 \%, 10 \%$, and $15 \%$ of gravel were applied, in the absence or presence of inoculation, in addition to the treatment in which the highest dose of gravel was applied (20\%) in the presence of mycorrhizal inoculation (Figure 1B).

\section{DISCUSSION}

The gravel used in the present study conferred the saline character $\left(\mathrm{CE} \geq 7 \mathrm{dS} \mathrm{m}^{-1}\right)$, which refers to the high salinity in the formulated substrates, which increased as the applied dose of the residue increased. In addition, the two highest gravel doses $(15 \%$ and $20 \%$ ) conferred the solodic character (SSIa $=6-15 \%)$ to the substrate, that is, the presence of high levels of sodium. Both the saline character and the solodic character of the soil or substrate are unfavorable for most plant species (SANTOS et al., 2018). Under these conditions, the growth of plants practically stops, responding with a significant decrease in height and dry biomass of shoots and roots, in comparison with plants produced in non-saline substrate or which received the application of recommended corrective agents to minimize the salinity and high levels of sodium, such as calcium sulfate (plaster), sulfuric acid, or elemental sulfur (SOUSA et al., 2012). Although the application of gravel caused an increase in base saturation $(>50 \%)$ in the substrate, this variable cannot be considered as an indicator of greater material fertility, due to the high sodium content present in the formulated substrates (SANTOS et al., 2018).

In fact, when the three highest gravel doses $(10 \%, 15 \%$, and $20 \%)$ were applied to the substrate composition, the lowest values for all growth variables (height, stem diameter, leaf area index, dry shoot and root biomass) were observed for seedlings of Colubrina glandulosa, in comparison with the application of the lowest gravel dose (5\%) and the absence of the application of gravel. The two highest gravel doses (15\% and 20\%) applied to the substrate also resulted in other aspects considered non-positive, such as the increase in the levels of sodium and lead in the shoots, and a decrease in the rate of root colonization by AMF of the Colubrina glandulosa seedlings.

The decrease in plant growth and the increase in sodium content in the dry biomass of the shoots are a reflection of high levels of this element and of salts in general in the substrate, which cause osmotic stress and alterations in the physiological response of the plants, which can be decreased with the application of correctives to the substrate, depending on the tolerance of the plant species to these conditions (SOUSA et al., 2012). The toxic effect of sodium is also due to the inhibition of the absorption of nutrients by the root system, because of the competition of the sodium ion with the potassium ions, mainly, in addition to calcium and magnesium (TAIZ; ZEIGER, 2004). Under greenhouse conditions, the excessive accumulation of sodium in the shoots of seedlings of Jatropha curcas L. (pinhão-manso) caused visual symptoms of toxicity (necrotic spots), which were mitigated by the presence of adequate levels of potassium in the soil solution, as these elements have a strong antagonism in terms of transport rates in the xylem to the stem, petioles, and leaves (RODRIGUES et al., 2012).

In general, the increase in the availability of phosphorus in the soil, for plants, is pointed out as one of the main limiting abiotic factors for the formation of symbiosis and, in this way, there is an inverse relationship between the content of bioavailable phosphorus in the soil and rates of root colonization by AMF (RENUKA et al., 2012). In seedlings of Apuleia leiocarpa produced in a greenhouse, the rate of root colonization by AMF decreased with the increase in the availability of phosphorus in the substrate (OLIVEIRA JÚNIOR et al., 2017). The greater availability of nutrients in the soil solution, notably phosphorus, decreases the activity of the root exudate responsible for stimulating pre-symbiotic growth of the fungi, and can lead to the degradation of the arbuscular fungus by the host (BREUILLIN et al., 2010). This is because it is not advantageous for the plant to spend the necessary investment in energy for the formation and maintenance of the mutualistic symbiosis, since in this case, the mycorrhiza can become a drain of photoassimilates from the host plant, without the proper nutritional benefit being provided by the mycorrhizal fungi.

However, in the present study, the rates of root colonization by AMF were higher for seedlings produced on the substrate without the application of gravel, where the available phosphorus was higher, in relation to the substrate formulations that included the application of different gravel doses. Furthermore, there was no significant correlation between the rates of root colonization by AMF and the availability of phosphorus in the substrates. In 
contrast, the significant and negative correlation between the rates of root colonization by AMF and the exchangeable calcium content, electrical conductivity of the soil, and saturation by sodium, which showed an increase proportional to the gravel dose applied to the substrate, indicated that the increase in these variables compromised the establishment of mycorrhizal symbiosis. The increase in the availability of calcium may be associated with the generalized increase in the availability of nutrients in the soil for plants, a fact that contributes to the reduction in root colonization by AMF (CARRENHO et al., 2007). It is known that there is an association between decreased richness of the AMF community and high values of electrical conductivity and sodium availability in the soil solution (LIU et al., 2016). This fact may suggest that the formation of mycorrhizal symbiosis can be negatively affected, a fact that would explain the decrease in root colonization by AMF under such conditions.

Mycorrhizal inoculation benefited the growth of seedlings of Colubrina glandulosa in height and stem diameter of the seedlings, when compared to the absence of inoculation. However, this result was found only after 90 days in the substrate in which the gravel was not applied and, mainly, at 120 days after seedling transplantation, when there was a significant effect of the interaction between mycorrhizal inoculation and gravel doses, specifically with the application of $10 \%$ and $20 \%$ gravel doses. It is believed that this result was a reflection of the greater presence of effectively active secondary roots on that evaluation date, which are able to be colonized by the AMF, in comparison with the previous evaluation dates.

In this way, the feasibility of using the residue from oil well drilling in the formulation of the substrate for the production of seedlings of Colubrina glandulosa, at a dose of 5\% was demonstrated. This alternative contributes to a more sustainable final destination than the deposition of waste in landfills, and the probable contamination of soil and water. Other studies of seedling production of Colubrina glandulosa should be carried out, in order to evaluate not only the nutritional demands of the species, which are not yet known, but also their response to different formulations of substrate, including residues from different human activities, in the formulation of the substrate. In a study previously conducted in a greenhouse, the T8 treatment, which combined bovine manure from a weather-beaten pen, soil from the surface level, sand, and vermiculite in the proportions of $20 \%, 60 \%, 10 \%$, and $10 \%$, respectively, with the presence of mycorrhizal inoculation, provided greater growth and nutrition for seedlings of Colubrina glandulosa, compared to seven other substrate formulations (CAMARA et al., 2017).

\section{CONCLUSIONS}

- The substrate formulated with the lowest dose of oil well drilling gravel (5\%), without mycorrhizal inoculation (mixture of spores of AMF species Gigaspora margarita, Rhizophagus clarus, and Dentiscutata heterogama), promoted significant increases in height, stem diameter, leaf area index, and dry biomass of the shoots and root, in addition to a higher rate of root colonization of Colubrina glandulosa seedlings by AMF, when compared to the substrate formulated with the other doses of gravel $(10 \%, 15 \%$, and $20 \%)$, at 120 days after transplantation of the seedlings.

\section{REFERENCES}

BRANCALION, P. H. S.; MONDO, V. H. V.; COELHO, A. D. L. Escarificação química para a superação da dormência de sementes de saguaraji-vermelho (Colubrina glandulosa Perk. - Rhamnaceae). Revista Árvore, Viçosa, v. 35, n. 1, p. 119-124, 2011.

BREUILLIN, F.; SCHRAMM, J.; HAJREZAEI, M.; FAVRE, P.; DRUEGE, U.; HAUSE, B.; BUCHER, M.; KRETZSCHMAR, T.; BOSSOLINI, E.; KUHLEMEIER, C.; MARTINOIA, E.; FRANKEN, P.; SCHOLZ, U.; REINHARDT, D. Phosphate systematically inhibits development of arbuscular mycorrhiza in Petunia hybrida and represses genes involved in mycorrhizal functioning. The Plant Journal, Oxford, v. 64, p. 1002-1017, 2010. CAENN, R.; DARLEY, H. C. H.; GRAY, G. R. Composition and properties of drilling and completion fluids. In: Introduction to drilling fluids. 6 ed. Oxford: Gulf Professional Publishing, p. 1-37, 2011.

CAMARA, R.; FONSECA JÚNIOR, A. M.; SOUSA, A. C. O.; PEREIRA, M. G.; OLIVEIRA JÚNIOR, J. Q. Influência do substrato e inoculação micorrízica na produção de mudas de Colubrina glandulosa Perkins. Floresta, Curitiba, v. 47, n. 4, p. 449-458, 2017.

CARRENHO, R.; TRUFEM, S. F. B.; BONONI, V. L. R.; SILVA, E. S. The effect of different soil properties on arbuscular mycorrhizal colonization of peanuts, sorghum and maize. Acta Botanica Brasilica, São Paulo, v. 21, n. 3, p. 723-730, 2007.

CORRÊA, C. C.; CRUZA, G. F.; VAZ JR., A. S. L.; ARAÚJO, B. S. A.; SILVA, A. A.; RODRIGUES, R. A.; LOMBA, R. F. T.; WALDMANN, A. T. A. Avaliação do potencial uso de bioglicerina como base para formulação 
de fluidos de perfuração aquosos para poços de petróleo e gás. Química Nova, São Paulo, v. 40, n. 4, p. 378-387, 2017.

FARIA, A. B. C.; ANGELO, A. C.; AUER, C. G. Disponibilidade de macronutrientes em Eucalyptus saligna cultivados com lodo de papel reciclado. Floresta, Curitiba, v. 45, n. 2, p. 261-272, 2015.

FREIRE, L. R.; CAMPOS, D. V. B.; ANJOS, L. H. C.; ZONTA, E.; PEREIRA, M. G.; BLOISE, R. M.; MOREIRA, G. N. C.; EIRA, P. A. Análise química de amostras de terra. In: FREIRE, L. R.; BALIEIRO, F. C.; ZONTA, E.; ANJOS, L. H. C.; PEREIRA, M. G.; LIMA, E.; GUERRA, J. G. M.; FERREIRA, M. B. C.; LEAL, M. A. A.; CAMPOS, D. V. B.; POLIDORO, J. C. Manual de calagem e adubação do Estado do Rio de Janeiro. Seropédica: Editora Universidade Rural, 2013, p. 87-105.

HAMMER, Ø.; HARPER, D. A. T.; RYAN, P. D. PAST: Paleontological Statistics software package for education and data analysis. Palaeontologia Electronica, California, v. 4, n. 1, p. 1-9, 2001.

LIMA, K. B.; RITER NETTO, A. F.; MARTINS, M. A.; FREITAS, M. S. M. Crescimento, acúmulo de nutrientes e fenóis totais de mudas de cedro-australiano (Toona ciliata) inoculadas com fungos micorrízicos. Ciência Florestal, Santa Maria, v. 25, n. 4, p. 853-862, 2015.

LIU, W.; ZHANG, Y.; JIANG, S.; DENG, Y.; CHRISTIE, P.; MURRAY, P. J.; LI, X.; ZHANG, J. Arbuscular mycorrhizal fungi in soil and roots respond differently to phosphorus inputs in an intensively managed calcareous agricultural soil. Scientific Reports, Londres, v. 6, 24902, 2016.

MARTINS, S. S. S.; SILVA, M. P.; AZEVEDO, M. O.; SILVA, V. P. Produção de petróleo e impactos ambientais: algumas considerações. HOLOS, Natal, v. 6, p. 55-74, 2015.

MELO JÚNIOR, J. L. A.; MELO, L. D. F. A.; FERREIRA, V. F.; ARAÚJO NETO, J. C. Longevidade das sementes de Colubrina glandulosa Perkins armazenadas. Revista de Ciências Agrárias, Recife, v. 42, n. 2, p. 394-401, 2019.

OLIVEIRA JÚNIOR, J. Q.; JESUS, E. C.; PEREIRA, M. G.; CAMARA, R.; FONSECA JÚNIOR, A. M.; SOUSA, A. C. O. Dependency and response of Apuleia leiocarpa to inoculation with different species of arbuscular mycorrhizal fungi. Revista Brasileira de Ciência do Solo, Viçosa, v. 41, e0160174, 2017.

PETROBRAS. Áreas de atuação exploração e produção de petróleo e gás. Disponível em: http://www.petrobras.com.br/pt/nossas-atividades/areas-de-atuacao/exploracao-e-producao-de-petroleo-e-gas/ Acesso em: 03 mar. de 2020.

RENUKA, G.; RAO, M. S.; RAMESH, M.; PRAVEEN KUMAR, V.; RAM REDDY S. Distribution and diversity of AM fungal flora in Godavari belt forests, Andhra Pradesh, India. Asian Journal of Experimental Biological Sciences, Uttar Pradesh, v. 3, n. 1, p. 228-235, 2012.

RODRIGUES, C. R. F.; SILVEIRA, J. A. G.; SILVA, E. N.; DUTRA, A. T. B.; VIÉGAS, R. A. Transporte e distribuição de potássio atenuam os efeitos tóxicos do sódio em plantas jovens de pinhão-manso. Revista Brasileira de Ciência do Solo, Viçosa, v. 36, n. 1, p. 223-232, 2012.

SAMPAIO JUNIOR, J.; AMARAL SOBRINHO, N. M. B.; Z, E.; MAGALHÃES, M. O. L. Barium and sodium in sunflower plants cultivated in soil treated with wastes of drilling of oil well. Revista Brasileira de Engenharia Agrícola e Ambiental, Campina Grande, v. 19, n. 11, p. 1100-1106, 2015.

SANTOS, H. G.; JACOMINE, P. K. T.; ANJOS, L. H. C.; OLIVEIRA, V. A.; LUMBRERAS, J. F.; COELHO, M. R.; ALMEIDA, J. A.; CUNHA, T. J. F.; OLIVEIRA, J. B. Sistema brasileiro de classificação de solos. Empresa Brasileira de Pesquisa Agropecuária. Embrapa Solos. 5a Ed. Brasília, DF: Embrapa. 356 p. 2018.

SILVA, K. A.; MARTINS, S. V.; MIRANDA NETO, A.; CAMPOS, W. H. Semeadura direta com transposição de serapilheira como metodologia de restauração ecológica. Revista Árvore, Viçosa, v. 39, n. 5, p. 811-820, 2015. SOUSA, F. Q.; ARAÚJO, J. L.; SILVA, A. P.; PEREIRA, F. H. F.; SANTOS, R. V.; LIMA, G. S. Crescimento e respostas fisiológicas de espécies arbóreas em solo salinizado tratado com corretivos. Revista Brasileira de Engenharia Agrícola e Ambiental, Campina Grande, v. 16, n. 2, p.173-181, 2012.

TAIZ, L.; ZEIGER, E. Fisiologia do estresse. In: TAIZ, L.; ZEIGER, E. Fisiologia vegetal. Califórnia: Artmed. 719 p. 2004.

TEIXEIRA, P. C.; DONAGEMMA, G. K.; FONTANA, A.; TEIXEIRA, W. G. Manual de Métodos de Análise de Solo. Empresa Brasileira de Pesquisa Agropecuária. Embrapa Solos. 3a Ed. Brasília, DF: Embrapa. 574 p. 2017.

USEPA. United States Environmental Protection Agency. Acid digestion of sediments, sludges, and soils. EPA method 3050B. 12 p. 1996.

USEPA. United States Environmental Protection Agency. Acid extraction of sediments, sludges, and soils. EPA method 3050. 14 p. 2008. 